\title{
Analisis Dan Perancangan Aplikasi Covid-19 di Kota Medan
}

\author{
${ }^{1}$ Suci Liandani, ${ }^{2}$ Ria Kristiani, ${ }^{3}$ Roni Yunis,${ }^{4} \mathrm{Hita}$ \\ Jurusan Sistem Informasi, Universitas Mikroskil, Medan \\ 노suci.liandani25@gmail.com, ${ }^{2} 172111771 @$ mikroskil.ac.id,,$\underline{3}$ roni@mikroskil.ac.id, $\underline{4}$ hita_tan@yahoo.com \\ *Penulis Korespondensi \\ Diajukan $\quad: 16 / 01 / 2022$ \\ Diterima $\quad: 17 / 01 / 2022$ \\ Dipublikasi : : 17/01/2022
}

\begin{abstract}
ABSTRAK
Jumlah kasus COVID-19 di Indonesia setiap harinya semakin meningkat sehingga menyebabkan sistem pelayanan dan fasilitas kesehatan rumah sakit yang tidak memadai perlu melakukan perubahan pelayanan menjadi berbasis online. Diperlukan aplikasi pelayanan COVID-19 di kota Medan yang dapat membantu mendapatkan informasi data COVID-19 dan pelayanan kesehatan (Pemeriksaan COVID-19, Rapid/Swab Test), membantu menghubungkan pasien dan dokter, menampilkan harga layanan, mengurangi jumlah antrian di klinik dan rumah sakit, mendapatkan layanan kesehatan, mencari bantuan tenaga kesehatan (dokter, perawat) menampilkan informasi, data gejala, aturan yang berlaku untuk pencegahan secara online tentang kondisi daerah berdasarkan titik koordinat. Metode yang digunakan dalam perancangan ini adalah design sprint yang terdiri dari 5 tahapan yaitu understanding, diverge, decide,prototype dan validate. Hasil dari perancangan ini adalah sebuah rancangan user interface yang dihasilkan hanya sebatas tampilan prototype desain. Sehingga dapat dikembangkan lagi dengan membangun aplikasi.
\end{abstract}

Kata Kunci: COVID-19; design sprint; user interface.

\section{PENDAHULUAN}

Coronavirus Disease 19 (COVID-19) merupakan penyakit yang disebabkan oleh Novel Coronavirus (2019-nCoV) atau yang kini dinamakan SARS-CoV-2. Tanda dan gejala umum infeksi COVID-19 antara lain gejala gangguan pernafasan akut seperti demam, batuk dan sesak napas hingga pada kasus yang berat menyebabkan pneumonia, sindrom pernafasan akut, gagal ginjal dan bahkan kematian (Direktorat, K. Primer, D. Jenderal, P. Kesehatan, and K. Kesehatan, 2020). Berbagai kebijakan telah diambil oleh pemerintah, termasuk salah satunya adalah menginstruksikan untuk bekerja, belajar, dan beribadah di rumah, atau dikenal dengan istilah Work From Home. Penerapan social distancing, physical distancing, dan kebijakan pembatasan sosial berskala besar (PSBB) ini bertujuan agar rantai penularan COVID-19 dapat terhambat di Indonesia (H. W. Taufik, 2020).

Transformasi model pelayanan manual dari tatap muka ke elektronik terus mengalami kenaikan yang signifikan di masa COVID-19. Diperlukan sistem layanan berbasis teknologi informasi dan komunikasi yang lebih efektif yang sesuai dengan keragaman manusia, pendidikan dan budaya masyarakat/kearifan lokal dalam membantu mempermudah akses kesehatan dengan informasi yang jelas dan terus menerus sehingga masyarakat cepat mengambil tindakan pemeriksaan, pengobatan dan isolasi mandiri ketika terinfeksi.

\section{STUDI LITERATUR Pengertian Sistem}

Dalam kamus Inggris-Indonesia John M. Echlos dan Hasan Shadily, "System" diartikan sebagai susunan. Secara umum sistem dapat didefinisikan sebagai sekumpulan hal atau kegiatan elemen atau subsistem yang saling bekerja sama atau yang dihubungkan dengan cara-cara tertentu 
sehingga membentuk satu kesatuan untuk melaksanakan suatu fungsi guna mencapai suatu tujuan. (Edhy Sutanta, 2016).Sedangkan menurut Jogianto terdapat dua kelompok pendekatan sistem di dalam mendefinisikan sistem yaitu pendekatan pada prosedur, dan pendekatan pada komponen-komponen atau elemen-elemen. Dari uraian pendapat pakar maka sistem merupakan suatu kumpulan dari elemen-elemen yang terorganisir, saling berinteraksi, saling tergantung satu sama lain dengan terintegrasi (E. Supriatna,2020).

\section{Pelayanan}

Pengertian pelayanan menurut Zein adalah sebuah kata yang bagi penyedia jasa merupakan sesuatu yang harus dikerjakan dengan baik. Sedangkan definisi pelayanan menurut Mahmoedin adalah suatu aktivitas atau serangkaian aktivitas yang bersifat tidak kasat mata yang terjadi sebagai akibat adanya interaksi antara konsumen dengan karyawan atau hal-hal lain yang disediakan oleh perusahaan pemberi pelayanan yang dimaksud untuk memecahkan permasalahan konsumen/pelanggan (R. D. Buana, 2020). Dengan demikian dapat disimpulkan bahwa pelayanan merupakan suatu bentuk sistem, prosedur atau metode tertentu yang diberikan kepada orang lain, dalam hal ini, kebutuhan pelanggan tersebut dapat terpenuhi sesuai dengan harapan atau keinginan pelanggan dengan tingkat persepsi mereka.

\section{COVID-19}

Penyakit Coronavirus 2019 (COVID-19) adalah penyakit menular yang disebabkan oleh sindrom pernapasan akut coronavirus 2 (SARS-CoV-2). Penyakit ini pertama kali diidentifikasi pada Desember 2019 di Wuhan, ibu kota provinsi Hubei China, dan sejak itu menyebar secara global, mengakibatkan pandemi coronavirus 2019- 20 yang sedang berlangsung. Gejala umum termasuk demam, batuk, dan sesak napas. Gejala lain mungkin termasuk nyeri otot, produksi dahak, diare, sakit tenggorokan, kehilangan bau, dan sakit perut. Sementara sebagian besar kasus mengakibatkan gejala ringan, beberapa berkembang menjadi pneumonia virus dan kegagalan multi-organ. Pada tanggal 4 April 2020, lebih dari 1.100.000 kasus telah dilaporkan di lebih dari dua ratus negara dan wilayah, mengakibatkan lebih dari 58.900 kematian, Lebih dari 226.000 orang telah pulih (Dede Kurniadi, 2020).

\section{Kebijakan Pelayanan Publik Untuk Mengatasi COVID-19}

\section{Djasri,2020):}

Berikut beberapa kebijakan pelayanan publik untuk mengatasi Covid 19 yaitu (H.

1. Lockdown sebagai pelayanan kebijakan alternatif di Indonesia

Kegiatan lockdown menjadi kebijakan Gubernur DKI Jakarta berdasarkan nomor 5 tahun 2020 tentang Peniadaan Sementara Kegiatan Peribadatan dan Keagamaan Di Rumah Ibadah Dalam Rangka Mencegah Penyebaran Wabah coronavirus disease (COVID-19). Kebijakan merupakan praktik sosial, ia bukanlah even yang tunggal atau terisolir. Dengan demikian, kebijakan merupakan sesuatu yang dihasilkan pemerintah yang dirumuskan berdasarkan dari segala kejadian yang terjadi di masyarakat.

2. Implementasi Kebijakan PSBB di Indonesia

Kebijakan PSBB diatur secara nasional melalui Peraturan Pemerintah Republik Indonesia Nomor 21 Tahun 2020 Tentang Pembatasan Sosial Berskala Besar Dalam Rangka Percepatan Penanganan Coronavirus Disease 2019 (COVID-19), peraturan tersebut secara operasional dijelaskan melalui Peraturan Menteri Kesehatan Nomor 9 Tahun 2020 tentang Pedoman Pembatasan Sosial Berskala Besar Dalam Rangka Percepatan Penanganan Coronavirus Disease 2019 (Pemerintah Indonesia, 2020 ). Kedua aturan tersebut secara tegas menetapkan serangkaian tindakan yang harus dilaksanakan guna mencegah penyebaran COVID-19 secara meluas.

\section{User Experience}

User experience adalah pengalaman pengguna yang diimplementasikan pada sebuah produk untuk orang-orang yang menggunakannya secara langsung. User Experience (UX) merupakan ilmu yang mengkaji tentang apa yang dirasakan oleh pengguna dalam menggunakan 
sistem sehingga mendapatkan kepuasan setelah menggunakannya. User experience sendiri mempunyai beberapa elemen seperti strategy, scope, structure, skeleton, surface.

User Experience (UX) bukan hanya apa yang pengguna lihat, bukan hanya menghasilkan desain yang menarik untuk dipandang, namun dapat menjawab mengapa desain tersebut seperti itu, desain yang mampu membuat pengguna nyaman ketika berhasil memperoleh tujuannya pada saat menggunakan produk atau aplikasi. Karena terdapat beberapa hal yang perlu dipelajari untuk dapat membuat UX yang baik dan sesuai.

\section{METODE}

Design sprint merupakan suatu kerangka desain produk fleksibel yang berguna untuk memaksimalkan peluang membuat sesuatu yang diinginkan orang. Ini adalah upaya sangat cocok dilakukan oleh tim kecil di mana hasilnya akan menentukan arah untuk produk atau layanan. Design sprint diciptakan oleh Jake Knapp dan dikembangkan di Google Venture pada tahun 2010.Design sprint membantu seluruh anggota tim guna meraih arah dan tujuan dengan jelas. Saat tim yang anda susun sedang membutuhkan suntikan motivasi maka design sprint bisa menjadi solusinya. Atau bagi anda yang di awal memulai bisnis juga sangatlah cocok menggunakan konsep ini untuk mengetahui keinginan konsumen dan hal apa yang ingin anda tawarkan melalui produk yang anda gagas (A. Purnomo,2020).

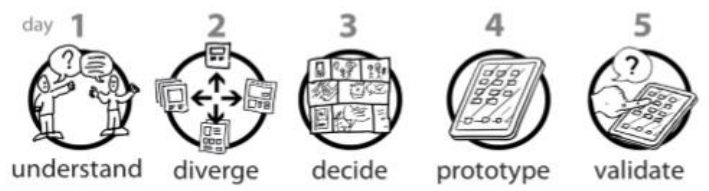

Gambar 1 Tahapan Design sprint

Implementasi suatu design sprint pada umumnya terdiri dari lima fase diskrit, yakni(A. Purnomo, 2020):

1. Hari pertama : Understand. Ini adalah tahap pertama dari Design sprint yang melakukan tentang pembahasan produk yang akan dibuat. Pada tahap ini kita membuat peta tantangan. Desain sprint ini digunakan untuk menyamakan gelombang/persepsi terhadap pembahasan produk. Hasil terpenting dari hari pertama ini adalah sketch user story.

Tabel 1 Peta tantangan / Journey Map

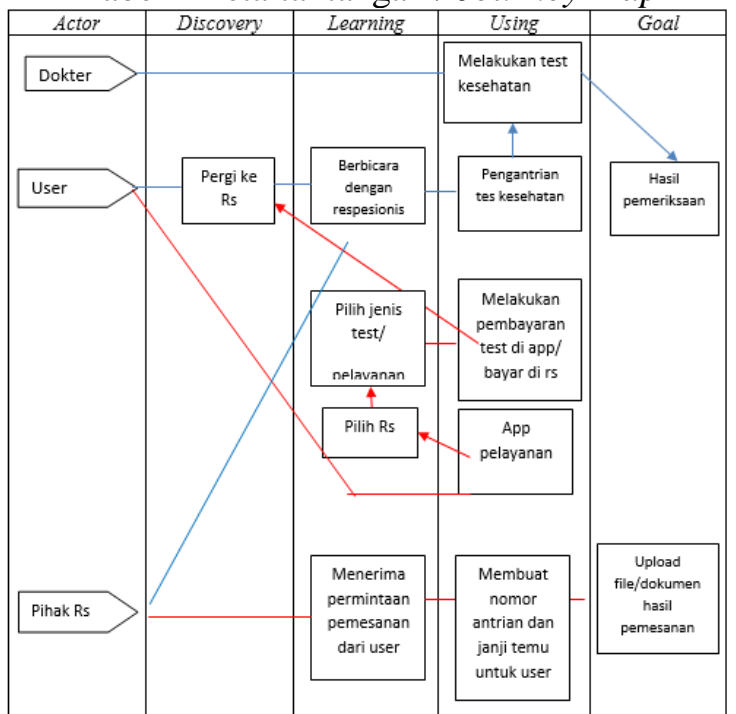

2. Hari kedua: Diverge. Ini adalah tahap kedua dari Design sprint yang melakukan penulisan / menggambarkan apa saja yang dipikirkan secara personal. Dilangkah ini hasil akhirnya menghasilkan beberapa design/sketching. Hal yang dilakukan adalah menggali dan menemukan beberapa tawaran solusi dengan ragam kegiatan yang menarik, seperti silent critique, crazy eights, mind map, dan lain-lain. 


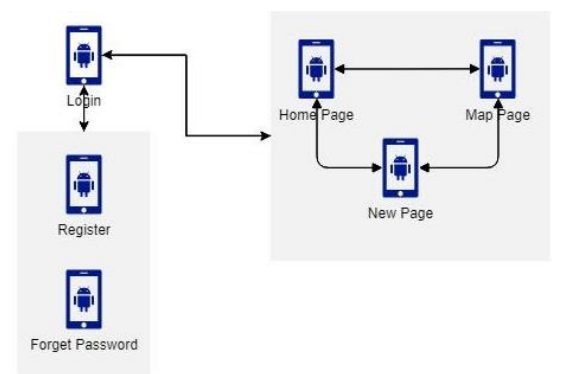

Gambar 2 Inspirasi Ide/Catatan

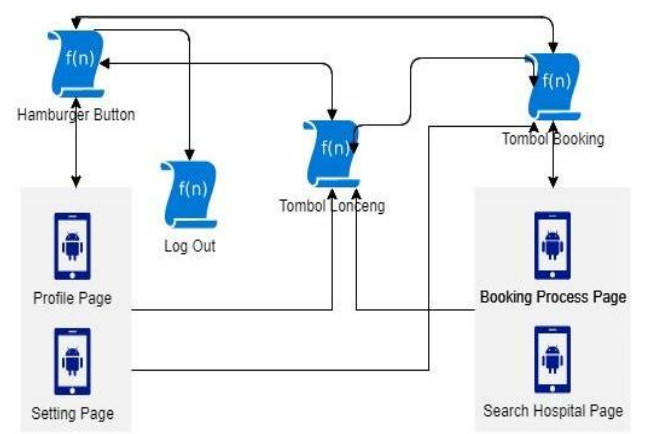

Gambar 3 Skema Navigation Bar

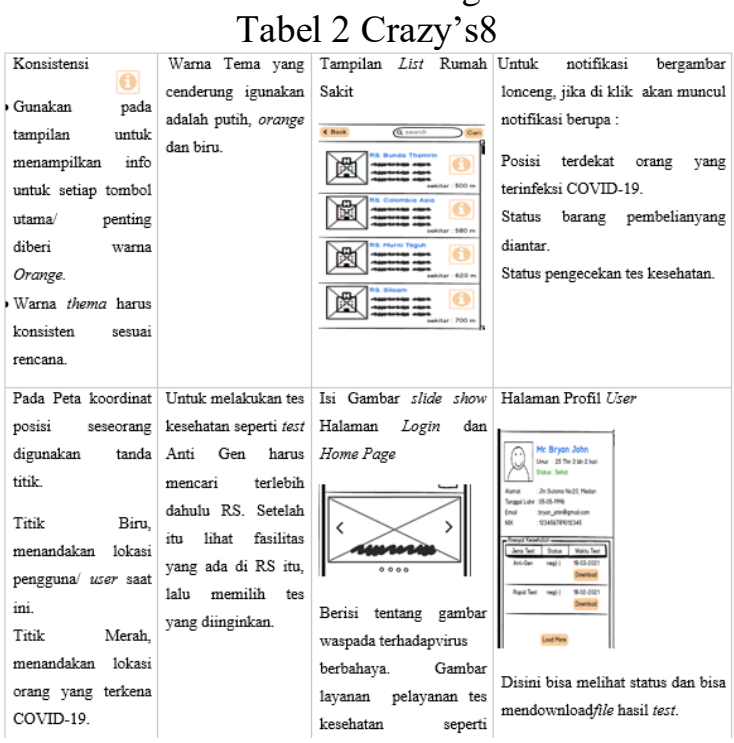

3. Hari ketiga: Decide. Pada langkah di hari ketiga ini beberapa solusi yang diperoleh dari langkah hari kedua, diberikan suatu porsi yang pas, relevan dan diulas dengan metode praktis tertentu untuk dapat dikreasi suatu prototype.

4. Hari keempat: Prototype. Satu hari untuk prototype, hal yang dilakukan dengan kerja sama tim dan beberapa tips serta trik yang bisa digunakan untuk menuntaskan prototype.

5. Hari kelima: Validate. Pada langkah hari terakhir ini prototype diuji coba secara langsung praktik lapangan kepada calon pengguna. Segala hal yang berlangsung direkam dan dicatat di suatu ruang observasi. Hasil nyata dari tindakan validate ini akan sangat menentukan pada proses selanjutnya, yaitu apakah termasuk iterasi besar atau iterasi kecil.

\section{PEMBAHASAN DAN HASIL (Times New Roman 12 Bold)}


1. Decide

Setelah dilakukan tahap diverge selanjutnya ke tahapan ke tiga yaitu decide dengan dihasilkan Storyboard berdasarkan Crazy'8 yang sudah dibuat sebelumnya. Storyboard dirancang berdasarkan alur penggunaan setiap tampilan layanan.

Berikut ini adalah beberapa rancangan Storyboard Aplikasi Pelayanan COVID-19 di kota Medan untuk pengguna user dan Dokter:
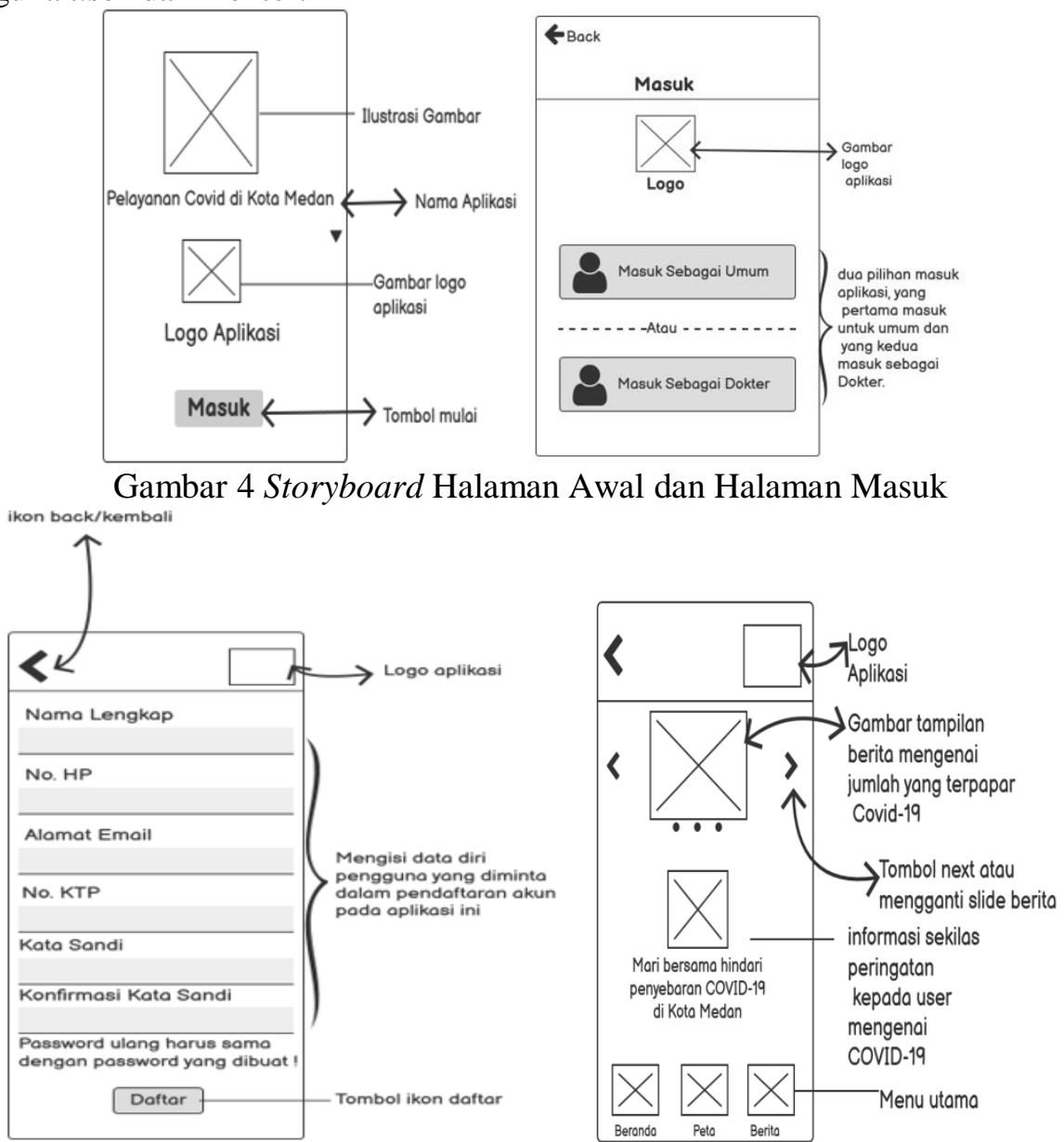

Gambar 5 Storyboard Daftar Akun dan Storyboard Beranda

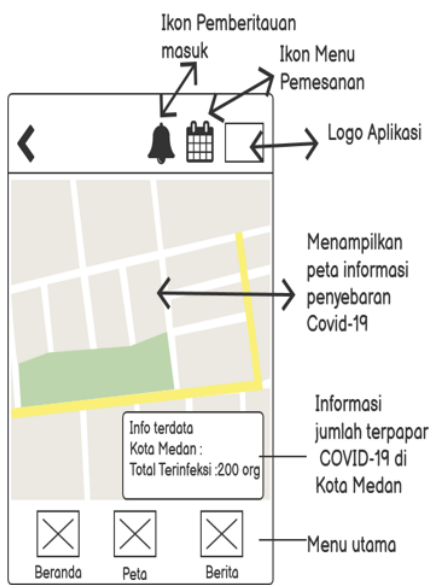

Gambar 6 Storyboard Peta 


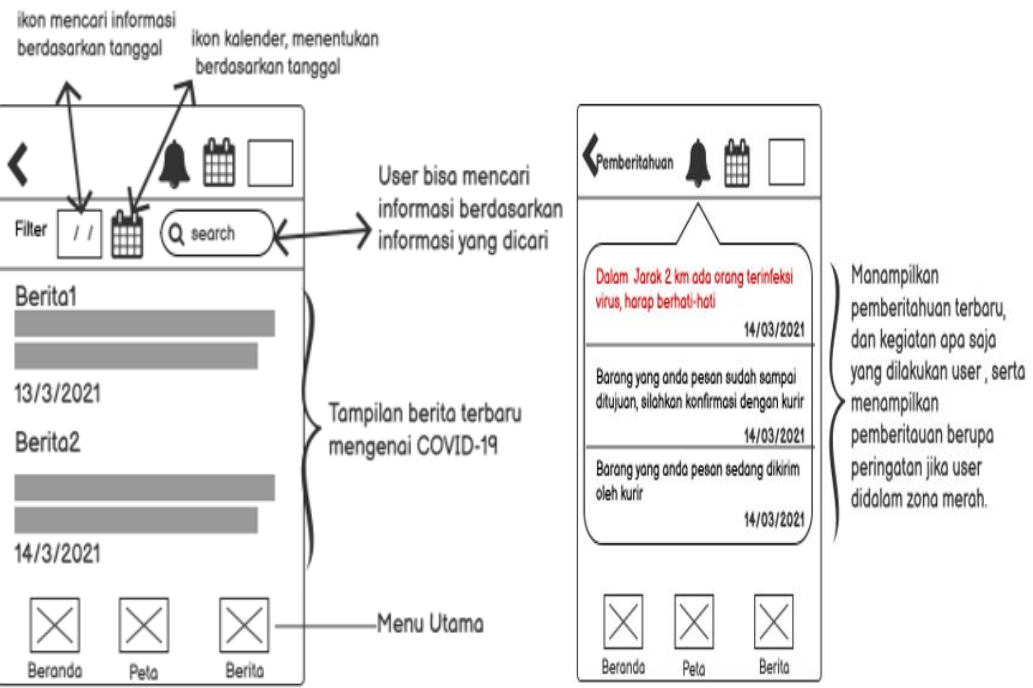

Gambar 7 Storyboard Berita dan Storyboard Pemberitahuan

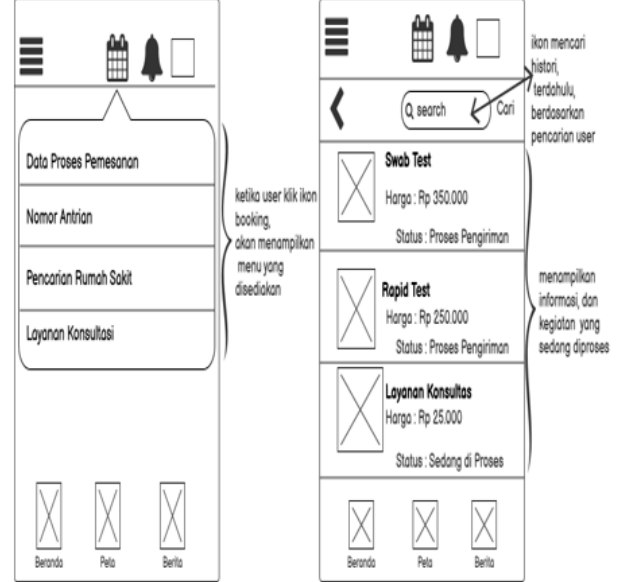

Gambar 8 StoryboardBooking/Pemesanan

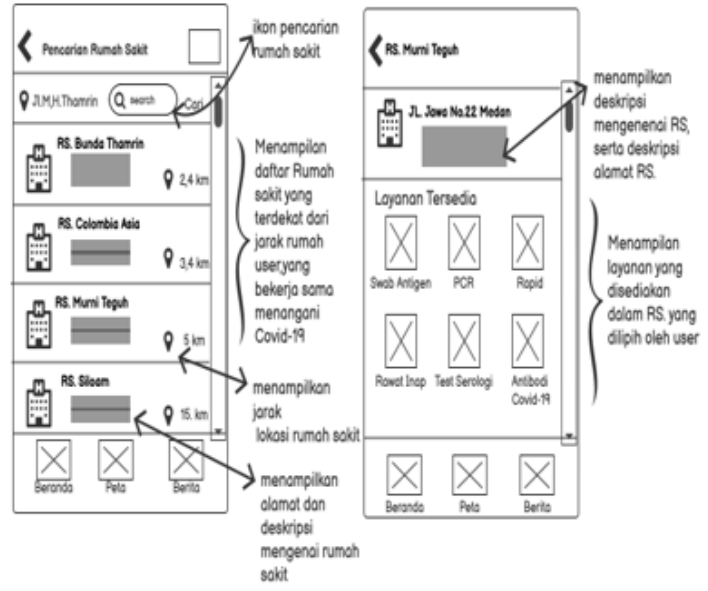

Gambar 9 Storyboard Rumah Sakit 


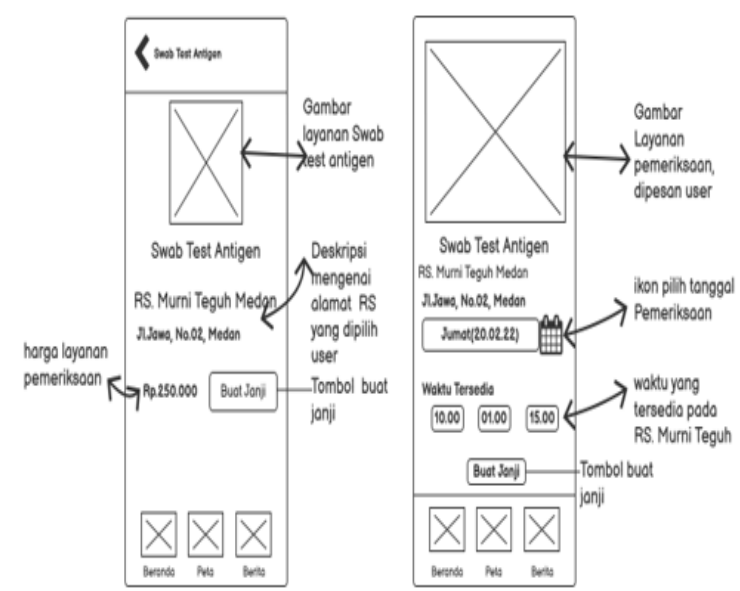

Gambar 10 Storyboard Layanan Rumah Sakit

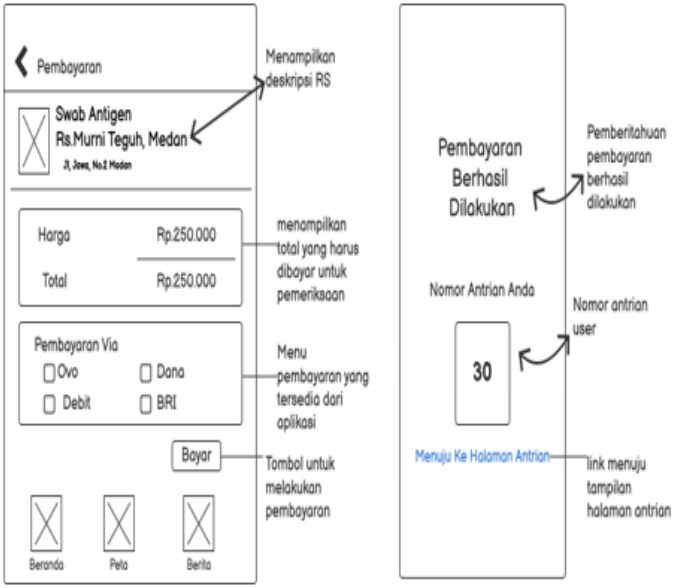

Gambar 11 Storyboard Pembayaran

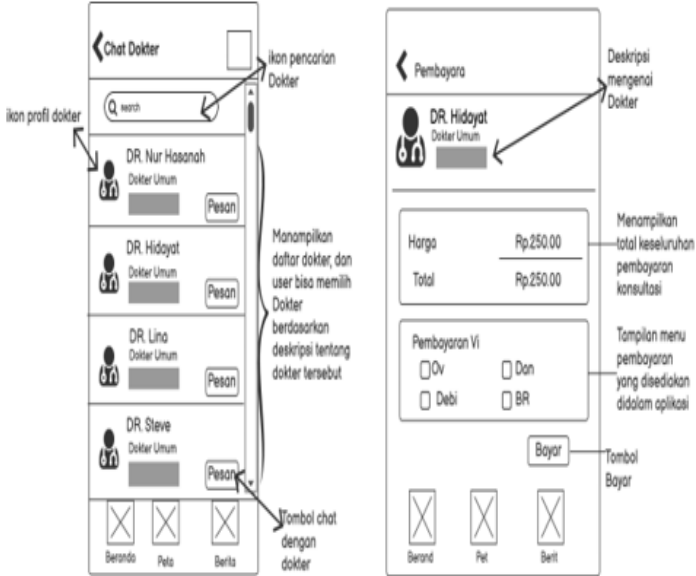

Gambar 12 Storyboard List Dokter 


\section{Prototipe/Prototype}

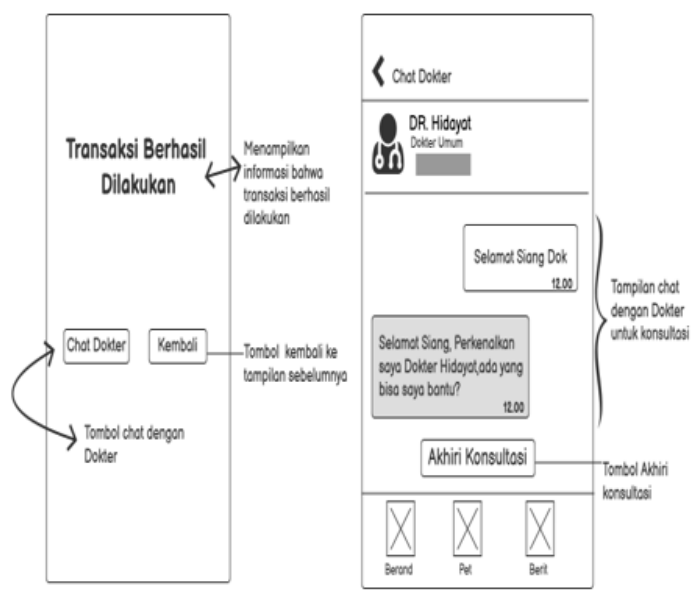

Gambar 13 Storyboard Chat Dokter

Setelah mengetahui Storyboard dari tahap deciding, kemudian dilakukan tahap prototype dengan menggunakan tools figma. Perancangan prototype ini akan berfokus pada membuat desain antarmuka yang menarik, dengan memudahkan pengguna mengetahui keberadaan pelayanan COVID-19 menggunakan aplikasi dan membuat pengguna nyaman dengan warna yang digunakan pada aplikasi. Berdasarkan pada Crazy's 8, untuk membuat desain antarmuka yang menarik, prototype dirancang dengan menggunakan font Source San Pro dan Fira Mono.

Warna yang akan digunakan pada aplikasi pelayanan COVID-19 di kota Medan yaitu warna biru dengan hexa color \#4EA8BC Tujuan dipilihnya warna biru yaitu warna yang populer di kalangan perusahaan besar, rumah sakit, dan maskapai penerbangan. Warna biru bisa memberi kesan kuat dan tabah atau sebaliknya ringan dan ramah. Biru digunakan untuk melambangkan kesalehan dan ketulusan dalam berbagai simbol dengan menggunakan warna yang konsisten, maka diharapkan tampilan user interface sistem menjadi konsisten dan dapat memudahkan user mengingat aplikasi.

Berikut ini adalah beberapa rancangan prototype Aplikasi Pelayanan COVID-19 di kota Medan untuk pengguna user dan Dokter:

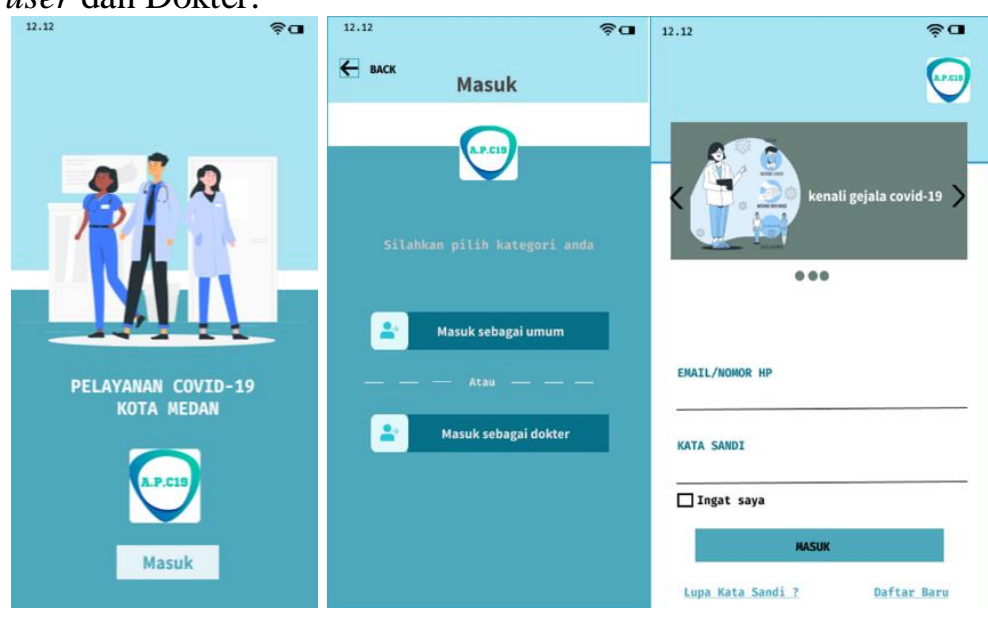

Gambar 14 Halaman Awal dan Halaman Masuk 


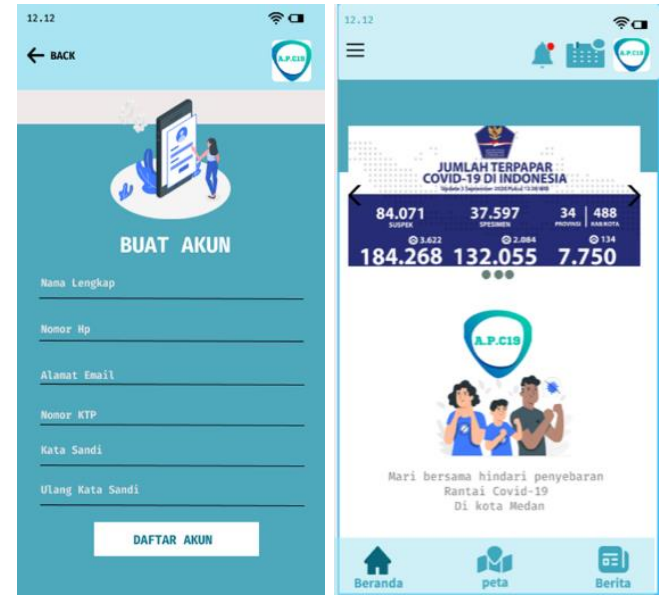

Gambar 15 Daftar Akun dan Beranda

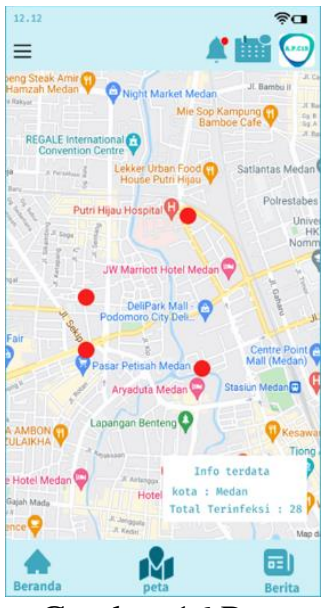

Gambar 16 Peta

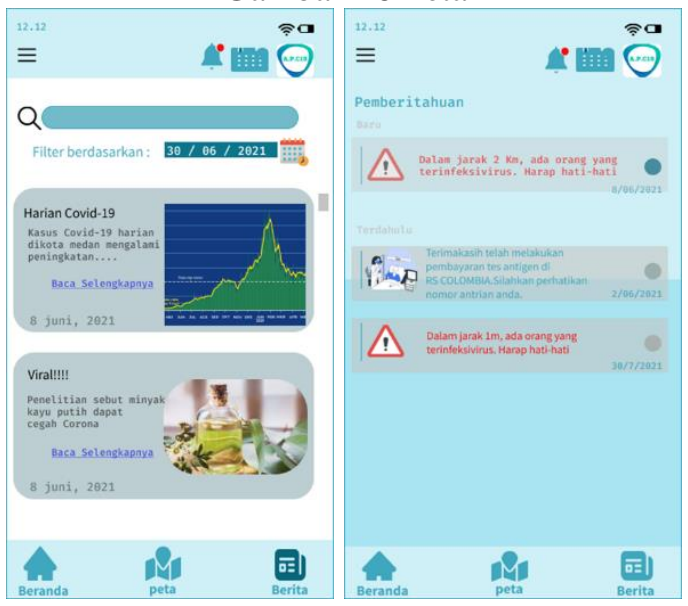

Gambar 17 Berita dan Pemberitahuan 


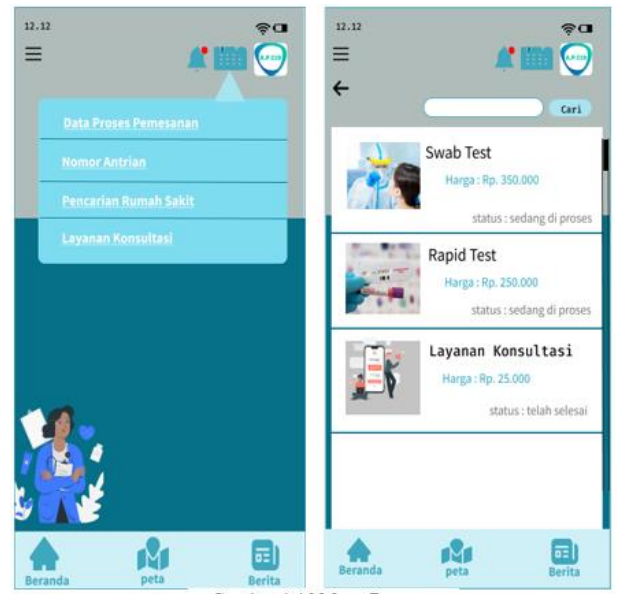

Gambar 18 Booking/Pemesanan

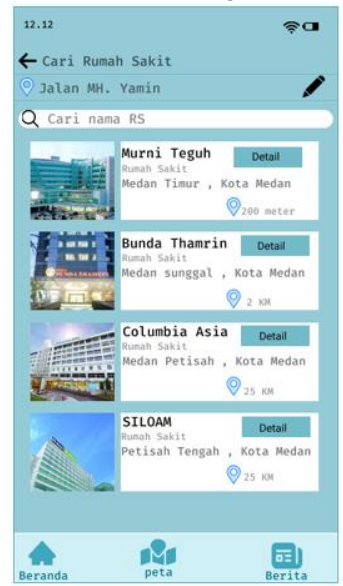

Gambar 19 Rumah Sakit

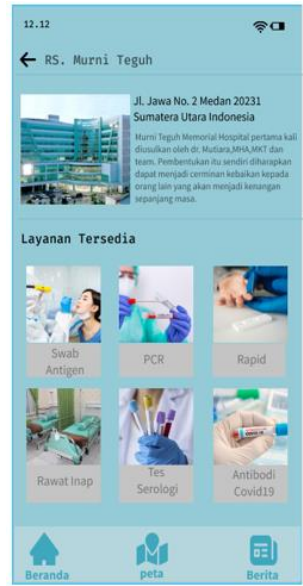

Gambar 20 Layanan Rumah Sakit 


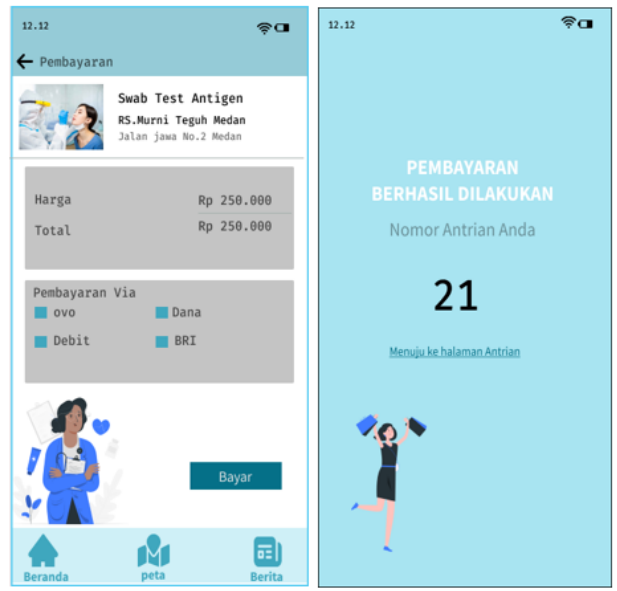

Gambar 21 Pembayaran

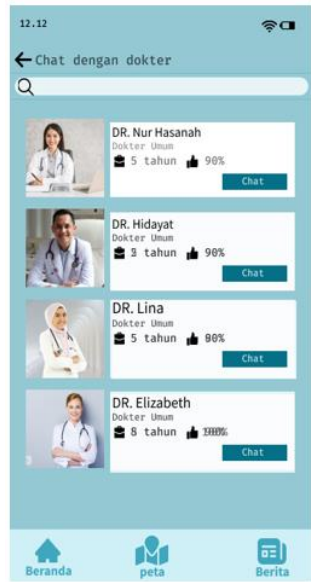

Gambar 22 List Dokter

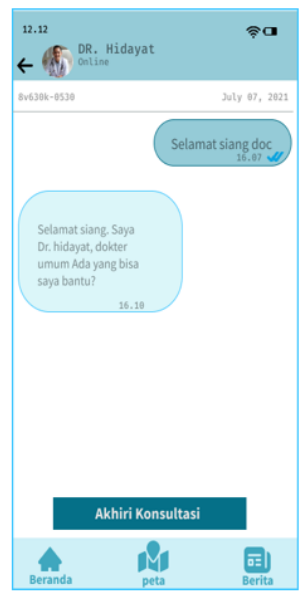

Gambar 23 Chat Dokter

\section{KESIMPULAN}

Berdasarkan hasil dan perancangan user interface pada aplikasi pelayanan COVID-19 di kota Medan menggunakan metode design sprint, kesimpulan yang dapat ditarik antara lain :

1. Secara keseluruhan, dengan memanfaatkan metode design sprint dapat memudahkan perancangan aplikasi mobile pelayanan Covid-19 kota Medan, perancangan yang dibuat ini mampu disesuaikan dengan permasalahan dan kebutuhan user. Pada tahap validasi diperoleh tanggapan responden mengenai prototype ini menyatakan nyaman dan mudah dipahami.

2. Berdasarkan evaluasi dengan modifikasi user interview/wawancara pengguna masyarakat umum dan dokter, hasil jawaban wawancara diubah menjadi daftar pola 
dibagi menjadi tiga hasil yaitu positif untuk responden yang memberikan tanggapan kemajuan prototype, negatif untuk responden yang memberikan tanggapan yang tidak membangun pada prototype dan beberapa responden memilih netral. Tujuannya agar semua dapat melihat hasil wawancaranya menjadi sangat jelas.

3. Skema warna yang disesuaikan dengan dunia kesehatan serta penggunaan font pada rancangan prototype sudah tepat digunakan karena dapat memudahkan pengguna dalam membaca dan membuat pengguna nyaman saat menggunakan aplikasi.

Berdasarkan hasil perancangan ini, maka penulis menemukan beberapa hal yang menjadi saran sebagai pertimbangan untuk merancang aplikasi kedepannya.yaitu :

1. Perancangan aplikasi ini khusus untuk pelayanan COVID-19 di kota Medan, sehingga aplikasi ini dapat dikembangkan lagi nantinya untuk layanan kesehatan umum. Untuk memberi kemudahan kepada pengguna yang ingin mendapatkan pelayanan kesehatan secara online.

2. Rekomendasi prototype desain yang telah dikembangkan dapat dilanjutkan dan direalisasikan dalam membangun aplikasi.

3. Untuk perancangan kedepannya diharapkan dapat menyelesaikan aplikasi pada tahap uji coba kepada pengguna secara langsung di rumah sakit dan masyarakat. Sehingga dapat diketahui respon dari pengguna setelah menggunakan aplikasi, hal ini dapat menjadi bahan evaluasi mengenai apa saja yang nantinya perlu untuk diperbaiki.

\section{REFERENSI}

Pelayanan pada masa pandemi COVID-19 di Pukesmas. Jakarta : Kementerian Kesehatan RI, 2020.

Birokrasi Baru Untuk New Normal: Tinjauan Model Perubahan Birokrasi Dalam Pelayanan Publik di Era COVID-19, Dialogue J. Ilmu Adm. Publik, vol. 2 2020, no. 1, pp. 1-18.

Wabah Corona Virus Disease (Covid 19) Dalam Pandangan Islam, SALAM J. Sos. dan Budaya Syar-i, vol. 7, no. 6, p. 4, 2020, doi: 10.15408/sjsbs.v7i6.15247.

Analisis Perilaku Masyarakat Indonesia dalam Menghadapi Pandemi COVID-19 dan Kiat Menjaga Kesejahteraan Jiwa," Sos. dan Budaya, Fak. Syariah dan Huk. Univ. Islam Negeri Syarif Hidayatullah Jakarta, vol. 53 2020, no. 7, pp. 1689-1699.

Design sprint: 5 Hari Desain Produk untuk Sukses Wirausaha, Inst. Teknol. Kreat. Bina Nusant. Malang, 2019, pp. 1-5.

Corona Virus dan Manajemen Mutu Pelayanan Klinis di Rumah Sakit," J. Hosp. Accredit., vol. 2 2020, no. 1, pp. 1-2. 